\title{
Return of the pythons: first formal records, with a special note on recovery of the Burmese python in the demilitarized Kinmen islands
}

Chung-Wei You', Yen-Po Lin ${ }^{1}$, Yen-Hsueh Lai ${ }^{2}$, You-Ling Chen ${ }^{3}$, Yao Tang ${ }^{4}$, Shih-Ping Chou' ${ }^{1}$ Hong-Yi Chang ${ }^{5}$, Robert T Zappalorti ${ }^{6}$ and Si-Min Lin $^{1^{*}}$

\begin{abstract}
Background: We report the first formal records and population recovery of wild Burmese pythons (Python molurus bivittatus) in the Kinmen islands, which are located $2.1 \mathrm{~km}$ from the Chinese coastline and are under military control of the Taiwanese government. During the Cold War period, bombardments by China destroyed most of the buildings and vegetation on the island, possibly extirpating the python population. In recent years, political tensions have subsided, and 95\% of the military forces have been withdrawn from the islands, allowing pythons and other wildlife populations to recover 40 years after being extirpated. Increased python predation on small livestock has recently become a nuisance to farmers, villagers, and aboriginal people, who are unaware of old python records from the island and therefore regard them as invasive pests.

Results: In order to clarify the origin of this python population, mitochondrial cytochrome $b$ and $\mathrm{COI}$ genes were sequenced from 33 pythons from Kinmen, Fuzhou Zoo (China) and pet traders (Vietnam). Molecular phylogeny and haplotype networks showed a close relationship between Kinmen and Chinese populations, rejecting the speculation from local people that pythons were introduced from Southeast Asia. Population expansion of the python in recent years might be relevant to the retreat of the army, illustrating a novel case of demilitarized zone protecting wildlife.

Conclusions: Since Kinmen Island has a similar latitude and climatic factors as the Everglades National Park in southern Florida (USA), where the Burmese python has become established, ecological and physiological research on the Kinmen population has potential value for comparative studies of habitat selection and niche modeling. Research on this new population could facilitate development of management plans for the Kinmen Island population and possibly help with managing the invasive population in the Florida Everglades.
\end{abstract}

Keywords: Demilitarized zone (DMZ); Everglades National Park; Invasive species; Temperature tolerance

\section{Background}

Buffer zones, separating countries or territorial entities, are sometimes established to reduce military conflicts between different nationalistic, political, or ideological groups. Although prior military actions may have resulted in the local extinction of flora and fauna, these areas can become refugia for wildlife after the establishment of corridors (Kim 1997; Draulans and Krunkelsven 2002;

\footnotetext{
* Correspondence: fish@ntnu.edu.tw

${ }^{1}$ Department of Life Science, National Taiwan Normal University, No. 88,

Tingchou Road, Section 4, Taipei 11677, Taiwan

Full list of author information is available at the end of the article
}

McNeely 2003). The most famous example of such a region is the demilitarized zone (DMZ) along the $38^{\circ} \mathrm{N}$ parallel line of the Korean Peninsula, which has separated North and South Korea for 60 years (Kim 1997; McNeely 2003). In spite of heavy military deployment along this region, the DMZ provides a sanctuary for many rare wild animals and plants (Higuchi et al. 1996; Kim 1997). Similar cases were described in Vietnam (Dillon and Wikramanayake 1997), Guinea (Fairhead and Leach 1995), and several eastern European countries (McNeely 2003). These examples indicate that neglected landscapes created by human conflicts may provide 
suitable habitats for wildlife by limiting human access and population densities (Dudley et al. 2002; McNeely 2003).

Kinmen, comprising Kinmen $\left(134.3 \mathrm{~km}^{2}\right)$ and Lesser Kinmen $\left(14.9 \mathrm{~km}^{2}\right)$ Islands, is located roughly $2 \mathrm{~km}$ from the southeastern coastline of China (Figure 1A). After World War II, civil war in China led to the separation of
China and Taiwan. Kinmen is one of the few islands located close to the Chinese coastline but under the military control of Taiwan. In Aug. 1958, the fierce 'Bombardment of Kinmen' began, which destroyed almost all of the buildings and vegetation on the two islands. Less-intense bombardments between the two sides (occurring once every 2 days) lasted for 21 years
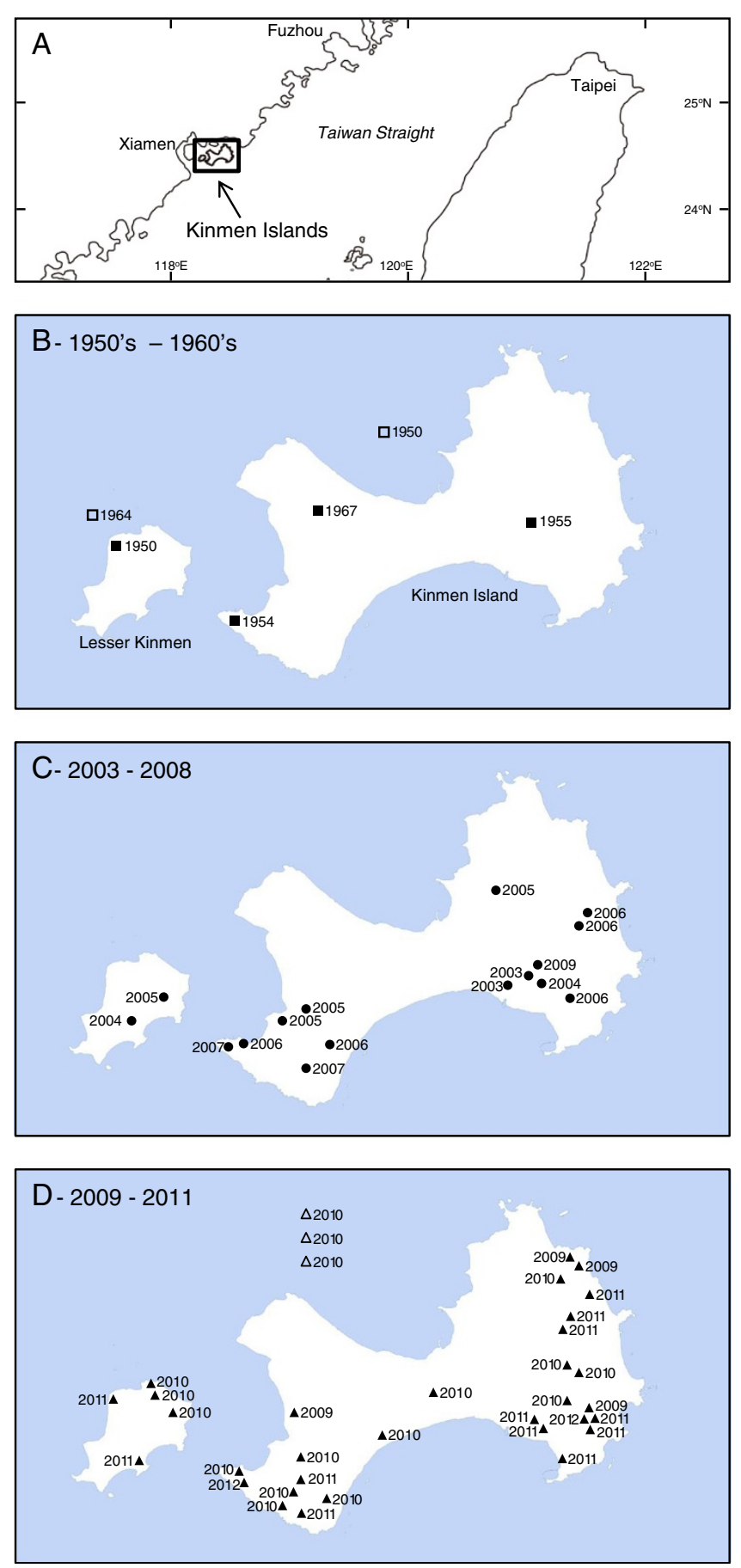

Figure 1 Location of Kinmen (A) and demographic fluctuations of Python molurus bivittatus population in different periods (B-D). 
until 1979, when both sides backed off of this prolonged and exhausting confrontation.

To defend the island against the Chinese army, approximately 100,000 Taiwanese soldiers were stationed on Kinmen during the Cold War, leading to an extremely high human population density on these islands. For shelter from artillery bombardments, most military facilities were built in underground tunnels. During this period, human activities associated with military operations destroyed most of the wildlife on the island. However, political tensions between Taiwan and China relaxed after the Cold War. During the past two decades, the Taiwanese government gradually withdrew $95 \%$ of its military force from the islands. Since 2001, the Chinese and Taiwanese governments have agreed to use this island as a trade and transportation center, and now, fewer than 5,000 soldiers are housed on the island. Except for the main cities and harbor regions, most of the island is only partially developed, with large areas now abandoned by the military.

These disused areas have become refugia for wildlife on the southeastern coast of China, where most regions are densely populated and highly developed. In this paper, we report the first formal records of the Burmese python (Python molurus bivittatus, Figure 2A) from Kinmen. This species is among the largest python species in the world and is listed under Category II in CITES. With its rareness, potential financial value, risk of poaching, and ongoing population decline, this snake is also listed as a Class I protected species in China (Zhao 1998; Zhao et al. 1998). The python once occurred on the islands in the early twentieth century, when the natural environment was less damaged $(\mathrm{Hu}$ 1976). However, those records were neglected by biologists until 2009, when Shiang et al. (2009) first included this python in their handbook based on a news report from 1950. Until that time, scientists had not formally recognized that this snake lived on these islands.

Rediscovery of pythons on the islands began in 2003, when reported by local newspapers (Kinmen Daily News, 16 June 2003). Since then, farmers and villagers have increasingly reported python sightings. Most of the snakes were captured because of their predation at chicken, duck, or lamb farms (You et al. 2011). By the winter of 2009, so many pythons had been captured that this species was becoming a nuisance to local farmers, who were experiencing financial losses due to predation of livestock by the snakes. Numerous complaints to the county and Taiwanese central governments were filed, and the authorities were encouraged to provide funding for scientific research on the pythons.

One of the most controversial issues is the origin of these pythons, because local residents cannot recall seeing such large snakes in the last half century. As a trade

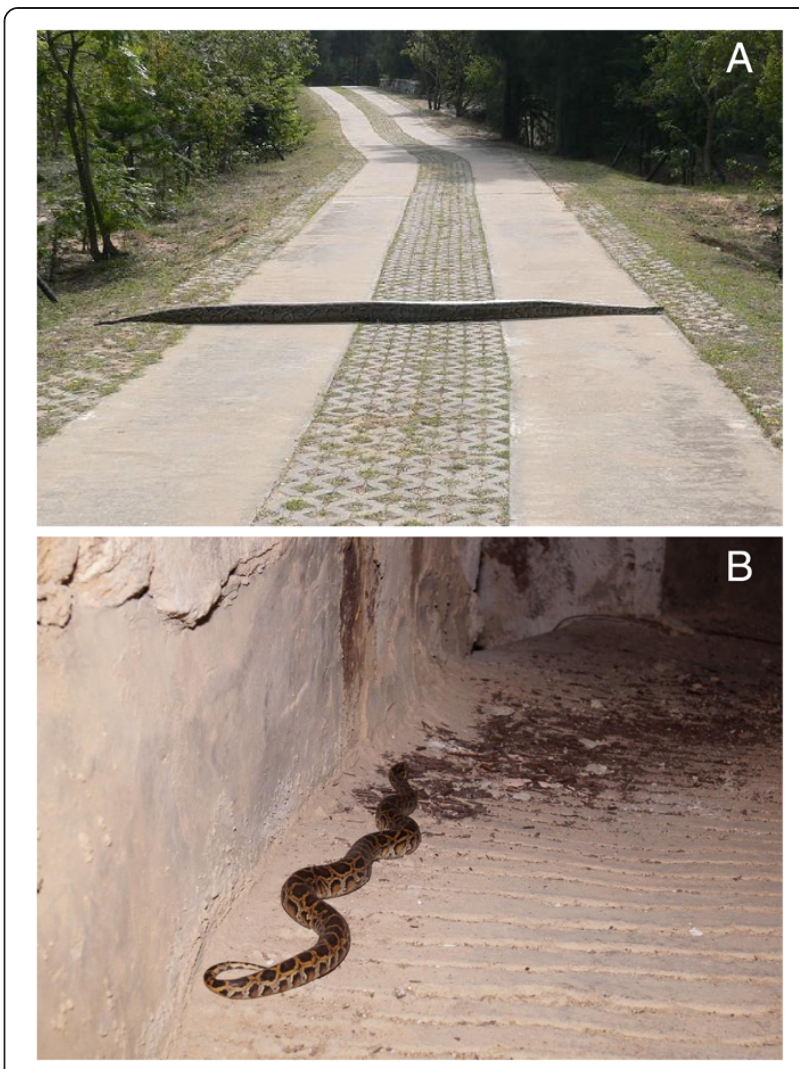

Figure 2 Habitats of the Burmese python. (A) Large adult Python molurus bivittatus crossing an abandoned military camp tank trail (photographed by Shun-Ren Cheng, 15 November 2011). (B) Pythons are frequently found sheltering in abandoned tunnels underground, which were built during the Cold War as protection from bombardment (photographed by Tien-Ding Tsai, 31 October 2011).

center between Taiwan and China, this region is notorious as a route for the illegal wildlife trade, including large numbers of yellow-margined box turtles (Cuora flavomarginata) and other herpetofauna for the pet trade (Chen and Lue 2010). Considering that pythons have rapidly invaded the state of Florida in the US, local people soon concluded that the presence of pythons was the result of introductions by pet traders. This hypothesis was strongly supported by field workers, including experienced birdwatchers, wildlife photographers, filmmakers, and ecologists (primarily mammalogists, ornithologists, and invertebrate zoologists from several different laboratories) who have spent decades investigating wildlife on the islands but had never seen or heard of a python (S.-M. Lin, personal interviews). Most of the snakes captured during these years were delivered to the Agriculture Bureau and died after being maintained under inappropriate conditions.

With this type of situation, the source of these pythons (i.e., invasive or native) should be clarified in a scientific manner. In order to identify the origin of the pythons in 
Kinmen, comparison of specimens from both natural and commercial populations is crucial. According to our understanding, most of the pythons sold in Taiwanese pet stores are imported from commercial snake farms in Vietnam. In this study, we compared mitochondrial sequences of snakes from Kinmen to those obtained from pet traders and the Fuzhou Zoo, respectively, representing potentially invasive and native populations. The major aims of this paper were to (1) formally document the occurrence of P. m. bivittatus in Kinmen; (2) clarify the origin(s) of this population; (3) reveal how the military presence influenced the demographic composition of these pythons; and (4) briefly discuss the research and conservation value of this population, as well as highlight its current crisis.

\section{Methods}

Morphological characteristics of Kinmen pythons

Twenty-two $P$. $m$. bivittatus from Kinmen, consisting of 7 males, 12 females, and 3 neonates, were included in the morphological measurement analysis. In order to reduce stress to the snakes and the risk of injury to investigators, the snakes were put under narcosis using a gas anesthesia system during this process. Eighteen characters were obtained from each individual, including 7 measurements (of length or weight) and 11 meristic characters (in numbers). The seven measurements were body weight (W), taken with a digital scale to the nearest $0.1 \mathrm{~kg}$; total length (TL), snout-vent length (SVL), and tail length (TAL) taken with a measuring tape to the nearest $0.1 \mathrm{~cm}$; and head length (HL), head width (HW), and head height $(\mathrm{HH})$ measured using digital calipers to the nearest $0.1 \mathrm{~mm}$. The 11 meristic characters included the number of dorsal scale rows (taken from the anterior one fourth, one half, and three fourth of the body), ventral scales, and numbers of subcaudal, supralabial, infralabial, supraocular, preocular, subocular, and postocular scales. Bilateral characters were taken from both sides. All mature snakes were given a nickname to identify them (Tables 1 and 2), marked with either a PIT tag or a radio transmitter, and released back into the wild. These procedures were carried out at the Taipei Zoo with the assistance of a licensed veterinarian (Y.-H. Lai).

Table 1 Measurements of the first 22 formally recorded Python molurus bivittatus in Kinmen

\begin{tabular}{|c|c|c|c|c|c|c|c|c|c|c|}
\hline Serial no. (nickname) & Sex & $\begin{array}{c}\mathrm{TL} \\
(\mathrm{cm})\end{array}$ & $\begin{array}{c}W \\
(k g)\end{array}$ & $\begin{array}{l}\text { SVL } \\
\text { (cm) }\end{array}$ & $\begin{array}{l}\text { TAL } \\
(\mathrm{cm})\end{array}$ & $\begin{array}{c}\mathrm{HL} \\
(\mathrm{cm})\end{array}$ & $\begin{array}{l}\mathrm{HW} \\
(\mathrm{cm})\end{array}$ & $\begin{array}{l}\mathrm{HH} \\
(\mathrm{cm})\end{array}$ & TAL/TL & $\mathrm{HL} / \mathrm{TL}$ \\
\hline PM015 (Donald Duck) & Female & 358.0 & 17.2 & 321.5 & 36.5 & 11.40 & 7.17 & 4.66 & $10.2 \%$ & $3.2 \%$ \\
\hline PM030 (Minnie Mouse) & Female & 349.0 & 21.6 & 311.0 & 38.0 & 10.53 & 7.14 & 4.95 & $10.9 \%$ & $3.0 \%$ \\
\hline PM017 (Goofy Dog) & Female & 338.8 & 24.8 & 300.5 & 38.3 & 10.37 & 6.91 & 4.50 & $11.3 \%$ & $3.1 \%$ \\
\hline PM035 (Mickey Mouse) & Male & 331.5 & 19.6 & 294.0 & 37.5 & 10.46 & 7.17 & 4.60 & $11.3 \%$ & $3.2 \%$ \\
\hline PM001 (Cinderella) & Female & 310.0 & 9.9 & 275.0 & 35.0 & 8.87 & 5.64 & 4.22 & $11.3 \%$ & $2.9 \%$ \\
\hline PM006 (Sleeping Beauty) & Female & 301.9 & 8.3 & 267.0 & 34.9 & 9.13 & 5.58 & 3.51 & $11.6 \%$ & $3.0 \%$ \\
\hline PM018 (Princess Ariel) & Female & 286.0 & 14.2 & 251.0 & 35.0 & 7.13 & 5.68 & 4.23 & $12.2 \%$ & $2.5 \%$ \\
\hline PM027 (Pumbaa) & Male & 280.0 & 9.0 & 245.5 & 34.5 & 7.83 & 5.15 & 3.03 & $12.3 \%$ & $2.8 \%$ \\
\hline PM012 (Snow White) & Female & 255.4 & 8.2 & 223.0 & 32.4 & 7.82 & 4.93 & 2.83 & $12.7 \%$ & $3.1 \%$ \\
\hline PM021 (Pocahontas) & Female & 252.0 & 8.5 & 221.5 & 30.5 & 7.19 & 5.18 & 3.36 & $12.1 \%$ & $2.9 \%$ \\
\hline PM005 (Aladdin) & Male & 246.0 & 7.1 & 214.0 & 32.0 & 7.08 & 4.96 & 2.87 & $13.0 \%$ & $2.9 \%$ \\
\hline PM023 (Simba) & Male & 236.5 & 5.4 & 203.5 & 33.0 & 6.90 & 4.72 & 2.96 & $14.0 \%$ & $2.9 \%$ \\
\hline PM028 (Timon) & Male & 236.0 & 5.1 & 206.0 & 30.0 & 7.25 & 4.26 & 2.78 & $12.7 \%$ & $3.1 \%$ \\
\hline PM013 (Mulan) & Male & 212.1 & 4.2 & 186.3 & 25.8 & 6.54 & 4.14 & 2.73 & $12.2 \%$ & $3.1 \%$ \\
\hline PM016 (Lord Voldemort) & Female & 210.5 & 3.9 & 186.0 & 24.5 & 6.95 & 4.43 & 2.66 & $11.6 \%$ & $3.3 \%$ \\
\hline PM020 (Woody) & Female & 207.5 & 4.3 & 181.0 & 26.5 & 6.80 & 4.95 & 3.15 & $12.8 \%$ & $3.3 \%$ \\
\hline PM026 (Princess Belle) & Female & 188.0 & 3.9 & 166.0 & 24.0 & 6.54 & 4.36 & 2.53 & $12.8 \%$ & $3.5 \%$ \\
\hline PM019 (Buzz Lightyear) & Female & 187.6 & 3.4 & 164.4 & 23.2 & 6.71 & 4.35 & 2.63 & $12.4 \%$ & $3.6 \%$ \\
\hline PM014 (Mowgli) & Male & 159.0 & 1.8 & 140.5 & 18.5 & 5.54 & 3.04 & 2.19 & $11.6 \%$ & $3.5 \%$ \\
\hline PM024 (Casper) & Neonate & 91.0 & 0.3 & 80.0 & 11.0 & 3.89 & 2.25 & 1.64 & $12.1 \%$ & $4.3 \%$ \\
\hline PM022 (Hunchback) & Neonate & 85.0 & 0.2 & 75.0 & 10.0 & 3.88 & 2.34 & 1.55 & $11.8 \%$ & $4.6 \%$ \\
\hline PM040 (Winnie) & Neonate & 82.0 & 0.3 & 73.0 & 9.0 & 3.79 & 2.19 & 1.45 & $11.0 \%$ & $4.6 \%$ \\
\hline$\overline{\text { Range }}$ & & $\begin{array}{c}82.0 \\
\text { to } 358.0\end{array}$ & $\begin{array}{c}0.2 \\
\text { to } 24.8\end{array}$ & $\begin{array}{c}73.0 \\
\text { to } 321.5\end{array}$ & $\begin{array}{c}9.0 \\
\text { to } 38.3\end{array}$ & $\begin{array}{c}3.79 \\
\text { to } 11.40\end{array}$ & $\begin{array}{c}2.19 \\
\text { to } 7.17\end{array}$ & $\begin{array}{c}1.45 \\
\text { to } 4.95\end{array}$ & $\begin{array}{c}10.2 \% \\
\text { to } 14.0 \%\end{array}$ & $\begin{array}{c}2.5 \% \\
\text { to } 4.6 \%\end{array}$ \\
\hline
\end{tabular}

$T L$ total length, $W$ weight, $S V L$ snout-vent length, TAL tail length, $H L$ head length, $H W$ head width, $H H$ head height. 
Table 2 Scalation of the first 22 formally recorded Python molurus bivittatus in Kinmen

\begin{tabular}{|c|c|c|c|c|c|c|c|c|c|}
\hline Serial no. (nickname) & $\begin{array}{c}\text { Dorsal } \\
(1 / 4 ; 2 / 4 ; 3 / 4)\end{array}$ & Ventral & $\begin{array}{l}\text { Subcaudal } \\
\text { (left/right) }\end{array}$ & $\begin{array}{c}\text { Supralabial } \\
\text { (left/right) }\end{array}$ & $\begin{array}{l}\text { Infralabial } \\
\text { (left/right) }\end{array}$ & $\begin{array}{c}\text { Supraocular } \\
\text { (left/right) }\end{array}$ & $\begin{array}{l}\text { Preocular } \\
\text { (left/right) }\end{array}$ & $\begin{array}{l}\text { Subocular } \\
\text { (left/right) }\end{array}$ & $\begin{array}{l}\text { Postocular } \\
\text { (left/right) }\end{array}$ \\
\hline PM015 (Donald Duck) & $56 ; 61 ; 41$ & 258 & $61 / 60+1$ & $13 / 12$ & 20/19 & $1 / 1$ & $2 / 2$ & $1 / 1$ & $3 / 3$ \\
\hline PM030 (Minnie Mouse) & $54 ; 69 ; 39$ & 257 & $55 / 55+1$ & $11 / 10$ & $17 / 16$ & $2 / 1$ & $1 / 2$ & $1 / 1$ & $2 / 2$ \\
\hline PM017 (Goofy Dog) & $55 ; 66 ; 47$ & 254 & $59 / 58+1$ & $11 / 10$ & $20 / 20$ & $1 / 1$ & $2 / 2$ & $1 / 1$ & $3 / 3$ \\
\hline PM035 (Mickey Mouse) & $53 ; 64 ; 40$ & 257 & $60 / 60+1$ & $11 / 11$ & 20/19 & $1 / 1$ & $2 / 2$ & $1 / 1$ & $3 / 3$ \\
\hline PM001 (Cinderella) & $59 ; 71 ; 41$ & 262 & $60 / 61+1$ & $12 / 13$ & $19 / 20$ & $1 / 1$ & $2 / 2$ & $1 / 1$ & $4 / 4$ \\
\hline PM006 (Sleeping Beauty) & $55 ; 69 ; 38$ & 256 & $64 / 65+1$ & $12 / 12$ & $20 / 19$ & $1 / 1$ & $2 / 2$ & $2 / 2$ & $3 / 4$ \\
\hline PM018 (Princess Ariel) & $55 ; 70 ; 41$ & 255 & $61 / 59+1$ & $11 / 11$ & $18 / 20$ & $1 / 1$ & $2 / 2$ & $1 / 1$ & $4 / 3$ \\
\hline PM027 (Pumbaa) & $59 ; 71 ; 46$ & 255 & $64 / 64+1$ & $10 / 10$ & 20/19 & $1 / 1$ & $2 / 2$ & $2 / 1$ & $3 / 4$ \\
\hline PM012 (Snow White) & $54 ; 66 ; 40$ & 256 & $64 / 66+1$ & $11 / 11$ & $18 / 19$ & $1 / 1$ & $2 / 2$ & $1 / 1$ & $4 / 3$ \\
\hline PM021 (Pocahontas) & $56 ; 68 ; 46$ & 258 & $64 / 65+1$ & $12 / 11$ & $20 / 19$ & $1 / 1$ & $2 / 1$ & $1 / 1$ & $3 / 3$ \\
\hline PM005 (Aladdin) & $55 ; 68 ; 42$ & 258 & $65 / 64+1$ & $12 / 13$ & $21 / 19$ & $1 / 1$ & $1 / 1$ & $2 / 2$ & $4 / 4$ \\
\hline PM023 (Simba) & $53 ; 65 ; 44$ & 255 & $63 / 64+1$ & $11 / 12$ & $20 / 20$ & $1 / 1$ & $2 / 2$ & $1 / 1$ & $4 / 4$ \\
\hline PM028 (Timon) & $57 ; 70 ; 40$ & 254 & $62 / 62+1$ & $10 / 12$ & $20 / 20$ & $1 / 1$ & $2 / 3$ & $1 / 1$ & $3 / 3$ \\
\hline PM013 (Mulan) & $54 ; 67 ; 39$ & 261 & $62 / 62+1$ & $11 / 12$ & $21 / 21$ & $1 / 1$ & $2 / 2$ & $1 / 1$ & $3 / 4$ \\
\hline PM016 (Lord Voldemort) & $55 ; 70 ; 39$ & 260 & $61 / 62+1$ & $11 / 12$ & $21 / 20$ & $1 / 1$ & $2 / 2$ & $1 / 1$ & $3 / 4$ \\
\hline PM020 (Woody) & $59 ; 71 ; 41$ & 255 & $65 / 66+1$ & $10 / 9$ & $20 / 20$ & $1 / 1$ & $2 / 2$ & $1 / 1$ & $3 / 3$ \\
\hline PM026 (Princess Belle) & $55 ; 65 ; 41$ & 255 & $61 / 62+1$ & $12 / 12$ & $18 / 20$ & $1 / 1$ & $2 / 3$ & $2 / 1$ & $3 / 4$ \\
\hline PM019 (Buzz Lightyear) & $54 ; 67 ; 42$ & 256 & $62 / 61+1$ & $12 / 11$ & $19 / 20$ & $1 / 1$ & $2 / 2$ & $2 / 2$ & $3 / 3$ \\
\hline PM014 (Mowgli) & $56 ; 67 ; 40$ & 259 & $64 / 64+1$ & $10 / 12$ & $20 / 19$ & $1 / 1$ & $2 / 2$ & $1 / 2$ & $4 / 4$ \\
\hline PM024 (Casper) & $55 ; 70 ; 44$ & 258 & $63 / 62+1$ & $12 / 11$ & 19/19 & $1 / 1$ & $3 / 2$ & $1 / 2$ & $3 / 4$ \\
\hline PM022 (Hunchback) & $63 ; 65 ; 41$ & 264 & $59 / 61+1$ & $10 / 11$ & 19/18 & $1 / 1$ & $2 / 2$ & $1 / 1$ & $3 / 3$ \\
\hline PM040 (Winnie) & $54 ; 69 ; 43$ & 256 & $62 / 62+1$ & $10 / 10$ & 19/18 & $1 / 1$ & $2 / 2$ & $1 / 2$ & $4 / 3$ \\
\hline \multirow[t]{3}{*}{ Mean \pm SE } & $1 / 4: 55.9 \pm 2.4$ & & & & & & & & \\
\hline & $2 / 4: 67.9 \pm 2.6$ & $257.3 \pm 2.7$ & $(62.0 \pm 2.6)+1$ & $11.3 \pm 0.9$ & $19.4 \pm 1.0$ & $1.0 \pm 0.2$ & $2.0 \pm 0.4$ & $1.2 \pm 0.4$ & $3.3 \pm 0.6$ \\
\hline & $3 / 4: 41.5 \pm 2.5$ & & & & & & & & \\
\hline \multirow[t]{3}{*}{ Range } & 1/4: 53 to 63 & & & & & & & & \\
\hline & 2/4: 61 to 71 & 254 to 264 & $(55$ to 66$)+1$ & 9 to 13 & 16 to 21 & 1 to 2 & 1 to 3 & 1 to 2 & 2 to 4 \\
\hline & 3/4: 38 to 47 & & & & & & & & \\
\hline
\end{tabular}

\section{Molecular techniques and phylogenetics}

Tissue samples from ventral scales were collected from a total of $33 \mathrm{P}$. m. bivittatus and were preserved in $95 \%$ ethanol. This collection included 26 snakes from Kinmen (including PM031, a snake collected by a fisherman in the ocean off the coastline), two from Fuzhou, China representing a typical Chinese population, and five from Vietnam representing a commercial population from pet traders. Total genomic DNA was isolated using the Qiagen DNeasy Blood \& Tissue Kit (Qiagen Inc., Crawley, UK). DNA was suspended in $1 \times$ TE buffer and stored at $-20^{\circ} \mathrm{C}$.

The complete mitochondrial cytochrome (Cyt) $b$ gene (1111 bp) and the anterior 5' region of the Cyt $c$ oxidase subunit I (COI, $1518 \mathrm{bp}$ ) were amplified by polymerase chain reactions (PCRs). Two sets of primers were designed from the consensus sequence of several serpent mitochondrial genomes (Dong and Kumazawa 2005): PCBL 5' -TTTCTGCCAGGRTTYTAACCTAGACC-3' and $\mathrm{PCBH}$ 5'-CCCAKCTTTGGTTTACAAGAACA-3' for Cyt $b$, and PCOF: 5'-CCCTTATGAGTAGATTTA CAGCCTA-3' and PCOR: 5'-GGATTGGGGCGTACA TATTGTTTAGT-3' for COI. PCRs were conducted in a $20-\mu$ reaction volume containing $1 \times$ PCR buffer $(10 \mathrm{mM}$ Tris- $\mathrm{HCl}$ at $\mathrm{pH} 9.0,50 \mathrm{mM} \mathrm{KCl}, 0.01 \%(w / v)$ gelatin, and $0.1 \%$ Triton X-100), $0.8 \mathrm{U}$ Taq DNA polymerase (Amersham Biosciences, Piscataway, NJ, USA), $0.2 \mu \mathrm{M}$ of each primer, $0.5 \mathrm{mM}$ dNTP, and $50 \mathrm{ng}$ template DNA. The PCR conditions were denaturated at $94^{\circ} \mathrm{C}$ for $3 \mathrm{~min}$, followed by 35 cycles at $94^{\circ} \mathrm{C}$ for $30 \mathrm{~s}, 54^{\circ} \mathrm{C}$ for $40 \mathrm{~s}$, and $72^{\circ} \mathrm{C}$ for $90 \mathrm{~s}$, with a final extension at $72^{\circ} \mathrm{C}$ for $10 \mathrm{~min}$ using an iCycler Thermal Cycler (Bio-Rad, Hercules, CA, USA). PCR products were purified with a PCR Product Pre-Sequencing Kit (USB, Cleveland, Ohio, USA) and subsequently used as the template for direct DNA sequencing reactions with a DYEnamic ET Dye Terminator Cycle Sequencing Kit (Amersham Pharmacia Biotech, Piscataway, NJ, USA). The same primers used for the PCR were used 
for the sequencing reactions. Sequencing products were run on a MegaBACE 1000 automated DNA sequencer (Amersham Biosciences). Sequences were determined in both directions, and the original signals were proofread using SEQUENCHER software vers. 4.9 (Gene Codes, Ann Arbor, MI, USA). The sequences obtained were compared to those of other snakes to ensure the accuracy of the PCR amplifications. The confirmed sequences were submitted to GenBank (JX401131-63 for Cyt $b$ and JX401098-130 for COI).

Haplotype genealogy of the pythons was represented by networks of Cyt $b$ (1111 bp) and COI (1518 bp) genes constructed using TCS (Clement et al. 2000). The two genes were combined to form a concatenated dataset used in phylogenetic tree construction. A maximumlikelihood (ML) tree was constructed using PAUP* 4.0 (Swofford 1998) with parameters set to the HKY model with a gamma distribution $(\mathrm{HKY}+\mathrm{G})$ according to the Akaike information criterion test implemented in jModeltest (Posada 2008). Statistical support of each node was determined using (1) 1,000 ML bootstraps conducted using Phyml (Guindon et al. 2010); (2) $10^{4}$ maximum-parsimony (MP) bootstraps conducted using PAUP (Swofford 1998); and (3) Bayesian posterior probabilities carried out using MrBayes 3.0 (Huelsenbeck and Ronquist 2001).

\section{Occurrence trends of pythons in Kinmen}

Very large snakes appearing on a small island cause considerable public interest, making these events favorites for news reporters. Without available scientific records, the local newspaper was our only way to trace fluctuations in python numbers. We screened old newspapers stored in the Kinmen library (dating back to the midtwentieth century) for python records and searched for newer records (after 2000) online. Python localities were located as precisely as possible on a map, based on descriptions in the newspaper articles. Data on changes in the size of military forces on Kinmen Island were available from http://army.mnd.gov.tw/kinman/kdc.htm.

\section{Results}

\section{Morphological characteristics of Kinmen pythons}

In 2009 to 2012, 22 snakes were measured while under narcosis. The maximum length was $358 \mathrm{~cm}$ and the maximum weight was $21.6 \mathrm{~kg}$, both of which were females (Table 1). Females seemed to grow larger in this population because only one of the six snakes exceeding $3 \mathrm{~m}$ was a male. The dorsal scales were smooth, averaging $55.9 \pm 2.4,67.9 \pm 2.6$, and $41.5 \pm 2.5$ in rows at the one fourth, one half, and three fourth positions of the body, respectively. Ventral scales averaged $257.3 \pm 2.7$ and ranged from 254 to 264, while subcaudal scales averaged $62.0 \pm 2.6$ pairs and ranged from 55 to 66 pairs.
Supralabial scales averaged $11.3 \pm 0.9$ and ranged from 9 to 13 , and infralabial scales averaged 19.4 \pm 1.0 and ranged from 16 to 21 . Numbers of supraocular, preocular, subocular, and postocular scales were 1, 2, 1, and 3, respectively, with very few individuals showing differences on either side of the body (Table 2). None of these measurements differs from records of the population in China (Zhao 1998; Zhao et al. 1998).

The ratio of TAL/TL ranged from $10.2 \%$ to $14.0 \%$. The model using sex as a factor with TL as the covariance explained the variance in the TAL/TL ratio (analysis of covariance (ANCOVA), $F_{2,16}=5.8927, p=0.0121$ ), and the TAL/TL value decreased as TL increased $\left(F_{1,16}=\right.$ $8.4232, p=0.0104)$. However, the sex effect was insignificant $\left(F_{1,16}=1.2621, p=0.2778\right)$. A similar situation occurred for the HL/TL ratio (ANCOVA, $F_{2,16}=3.3184$, $p=0.0623)$, with no sex difference $\left(F_{1,16}=0.9350, p=\right.$ $0.3480)$ but was negatively correlated to $\mathrm{TL}\left(F_{1,16}=\right.$ 6.4793, $p=0.0216)$. This means that males and females did not differ in TL or HL, but larger snakes had comparatively shorter tails and smaller heads. Neither value proportionally increased as snakes increased in body size.

\section{Origin of the recolonized population}

Sequencing of the mitochondrial Cyt $b$ and COI genes, respectively, yielded four and six haplotypes. ML, MP, and Bayesian analyses of mitochondrial sequences produced identical tree topologies (Figure 3A), showing the existence of two clades with a mean between-group divergence of 0.0063 (p-distance). Monophyly of the Kinmen and Fuzhou specimens was strongly supported by bootstrap values and Bayesian posterior probabilities. Similar results were revealed in haplotype networks of the Cyt $b$ (Figure 3B) and COI genes (Figure 3C), showing a close relationship between Kinmen and Fuzhou haplotypes, with a shared haplotype in the Cyt $b$ gene. These lines of evidence indicated that snakes appearing in Kinmen were more likely to be native rather than having originated from an invasive population exported from Southeast Asia.

\section{Demographic trends of pythons in Kinmen}

During the 1950s and 1960s, pythons were occasionally found, with four and two records from Kinmen Island and Lesser Kinmen Island, respectively (Figures 1B and 4). However, no pythons were reported in the 36 -year period from 1967 to 2003. From 2003 to 2008, 16 records were reported (Figure 1C). The frequency of snake records reported to the local fire brigade suddenly increased in late 2009 and peaked in 2010 (Figure 1D). Since 2011, the fire brigade was recommended that snakes immediately be released in nearby fields. At roughly the same time, the public media stopped reporting on these large snakes because they had become such common occurrences. These 


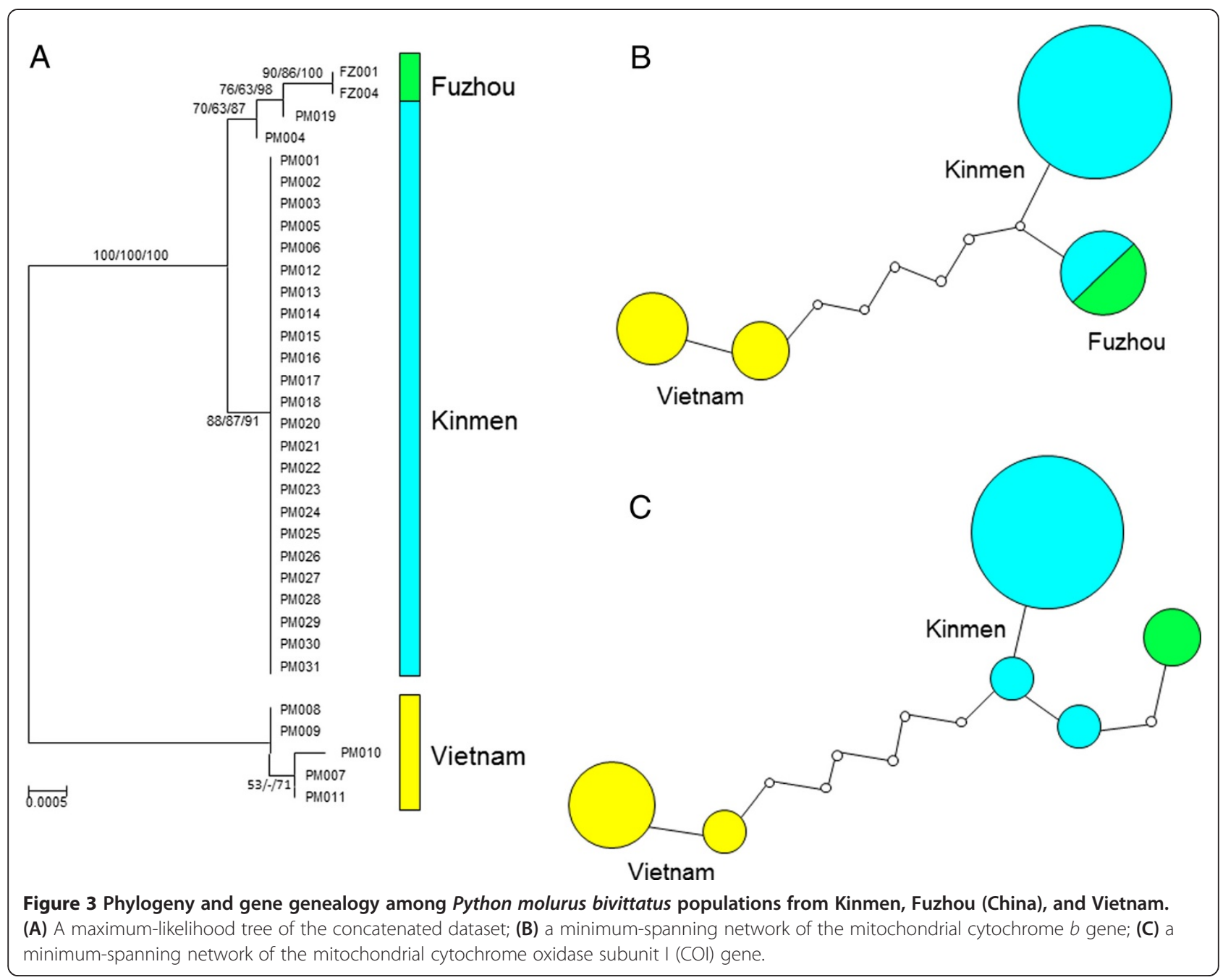

events made it difficult to obtain precise estimates after this period. With three neonates found since autumn 2010, P. m. bivittatus is believed to have established breeding populations on both Kinmen Island and Lesser Kinmen Island.

In contrast to snake numbers, military forces in this region have dramatically decreased over the last few decades (Figure 4). In 1987, the Taiwanese government withdrew roughly one half of the original military force, decreasing from 100,000 to 55,000 soldiers. From 1997 to 2000 , numbers were further reduced to 25,000 . Since 2001, the Chinese and Taiwanese governments have agreed to use Kinmen Island as a trade and transportation center and thus gradually decreased the number of soldiers to the current 5,000 people.

\section{Discussion}

\section{Pythons have reestablished their populations}

Molecular evidence indicated that the $P . m$. bivittatus population in Kinmen is more closely related to the geographically nearby Chinese population than to the commercial population of the pet trade, comprised mostly of animals imported from Vietnam. This result rejects the explanation that the pet trade in this species led to the establishment of $P . m$. bivittatus on the islands. In addition to this direct evidence, other indirect evidence includes (1) wild-type $P . m$. bivittatus is no longer as a popular pet in the wildlife trade because they are gradually replaced by those more valuable mutant forms from captive breeding populations; (2) because most snake farms are located in Southeast Asia, it is uneconomical to smuggle this species between China and Taiwan; (3) there are no pet stores or professional reptile keepers on the islands; and (4) unlike those Southeast Asian populations, the snakes seemed to have adapted well for the much cooler winter climate in Kinmen.

The most probable route for $P$. m. bivittatus recolonization of the Kinmen islands is by way of oversea dispersal. Located near the river mouth of the Jiulong River, Kinmen Island often receives large floating garbage 

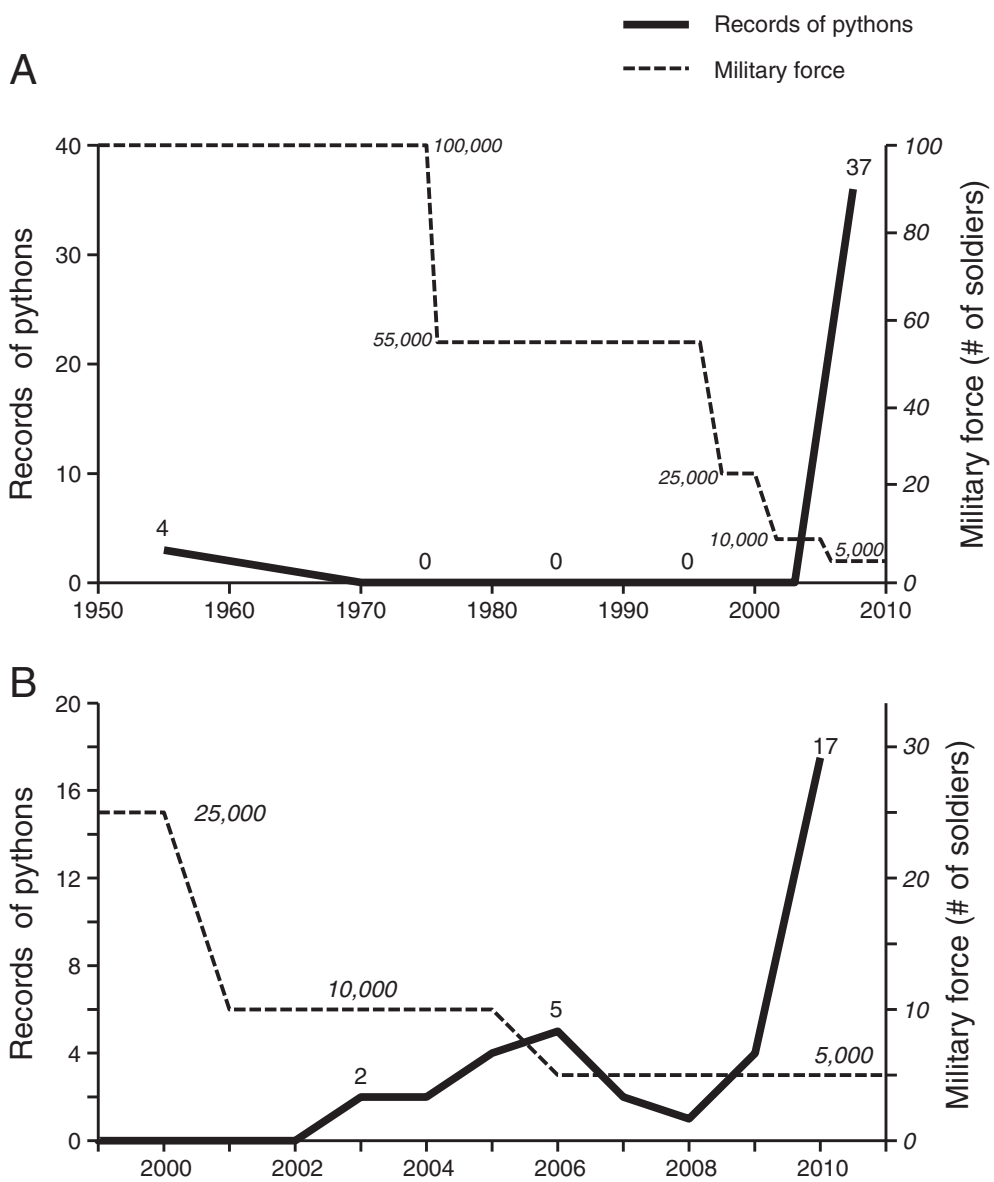

Figure 4 Numbers of Python molurus bivittatus records. From local newspapers compared to numbers of military forces (in numbers of soldiers) on Kinmen Island over larger (A) and smaller (B) time scales. Records after 2011 were not precise since the fire brigade was recommended to release the snakes immediately in nearby fields.

mats that wash up along the shore after heavy floods. After a typhoon in Aug. 2011, a fisherman found an adult female (PM031) floating a short distance off the Kinmen coastline. This record suggests that pythons could disperse this distance, especially if aided by heavy floods and floating debris. This possibility is supported by recent experiments demonstrating that pythons can readily survive in saline conditions even when fresh water is unavailable (Hart et al. 2011). An alternative possibility is that P. m. bivittatus was never completely extirpated from the islands, which is better preferred by some other herpetologists (M. E. Dorcas, personal communication). Pythons are secretive and cryptic, and tend to have very low individual detection probabilities. Although populations were depressed by over-harvesting during the military period, a small breeding population may have survived undetected.

\section{Python increases were associated with the withdrawal of military forces}

The first record of $P$. m. bivittatus on Kinmen can be traced back to the 1940s, when General Hu Lien, the commander of the Kinmen armed forces between 1949 and 1958, described the snake-eating culture of his soldiers. In his book Memories of Kinmen (Hu 1976), pythons were reported to grow 4 to $6 \mathrm{~m}$ long, weigh 30 to $50 \mathrm{~kg}$, and have a diameter at mid-body of over $35 \mathrm{~cm}$. Interestingly, this statement was neglected by earlier herpetologists, who may have mistaken this description as an over-exaggeration of large Elaphe species. The custom in the army of eating pythons was thought to 'increase the power of the soldiers.' Subsequently, overharvesting of these huge snakes is thought to have caused a demographic explosion of rodent populations, which caused serious agricultural damage. Overpopulation by destructive rodents was out of control until General $\mathrm{Hu}$ Lien ordered his troops to stop killing pythons (Hu 1976). However, the constant bombardment during military engagements might have pushed the python population past the tipping point toward near extirpation. Between 1950 and 1960, only six pythons were recorded on the island. The last python recorded in the twentieth century was in 1967 (Kinmen Daily News, 16 May 1967). 
As the army gradually left the island, the natural environment systematically recovered. The python is not the only species that has benefited from the army's withdrawal. Recently, mammalogists discovered a dense population of Eurasian otter (Lutra lutra) on the island, which is extremely rare in the neighboring region and has been extirpated in Taiwan (Hung et al. 2004). Chen and Lue (2010) discovered stable populations of the Chinese pond turtle (Chinemys reevesii), which was also extirpated in Taiwan. The large Kinmen wetland now sustains one of the largest wintering populations of Great Cormorants (Phalacrocorax carbo) in East Asia (Chang et al. 2008). A number of studies have documented population stability in the Blue-tailed bee-eater (Merops philippinus), which nests in artificial sand banks abandoned by the military (Yuan et al. 2006; Wang et al. 2009). The habitat of the horseshoe crab (Tachypleus tridentatus) on the mudflats is preserved in Kinmen, because the local people avoid the coastline due to fears of unexploded land mines (Chen et al. 2004).

The main reason for the increase in pythons on Kinmen in recent years appears to be the sudden increase in suitable habitats. Large forested areas, open grasslands, abandoned camps, and tunnels all provide suitable habitats for pythons. Most local villagers do not enter these areas because of the possibility of stepping on unexploded land mines. Radio-tracking also revealed that pythons consistently use old underground tunnels as overwintering shelters (Chou et al., unpublished data; Figure 2B). The increase in pythons is also likely related to increases in available prey. For example, in the early 2000s, typhoons destroyed several local bird farms and caused the escape of Korean ring-necked pheasants (Phasianus colchicus karpowi) and Indian peacocks (Pavo cristatus). Soon after this event, these two non-native birds established populations and now occupy all habitat types throughout the island (Hung et al. 2009). The sudden availability of these large, terrestrial birds may also have provided a rich food source for the pythons (Dove et al. 2011).

\section{Research, conservation, and threats to the pythons}

The python population on Kinmen provides a valuable opportunity to study their ecology, including habitat selection, home range size, and physiological ecology in a native habitat. In recent years, the exotic population of this python in southern Florida (US) has become the focus of biological invasion research (Engeman et al. 2011). Current debates are evaluating the potential for pythons to spread further northward into the southern US (Pyron et al. 2008; Rodda et al. 2009; Avery et al. 2010; Barker and Barker 2010; Dorcas et al. 2011; Rodda et al. 2011). Some of the arguments have originated due to difficulties with the accuracy of large-scale ecological niche modeling because there have been few physiological and ecological studies on pythons in their native geographical ranges. Under this situation, ecological and physiological information from a native python population has become extremely important.

The latitude of Kinmen Island $\left(24^{\circ} 23^{\prime}\right.$ to $\left.24^{\circ} 31^{\prime} \mathrm{N}\right)$ is similar to that of Everglades National Park in Florida $\left(24^{\circ} 50^{\prime}\right.$ to $\left.25^{\circ} 55^{\prime} \mathrm{N}\right)$, and these areas have similar average temperatures and precipitation. However, adaptations to cool-temperature environments, as well as the unique behavior of using abandoned underground military tunnels (Figure 2B), might have facilitated their survival in Kinmen. Since 2010, research concerning their home range, habitat use, and thermal biology has been conducted on this population. Our ongoing research with implantation of temperature data loggers could be compared to similar research of the Florida Everglades population (Mazzotti et al. 2011). Such comparisons may provide an opportunity for more-detailed mechanistic niche modeling of habitat selection, thus facilitating the development of management plans for both the native population in Kinmen and the invasive population in the Florida Everglades.

Unlike most DMZ cases in the world, however, pythons in Kinmen are still facing increasing pressure from tourism and habitat destruction. In order to attract curious tourists, more and more abandoned tunnels, which once served as shelter for the pythons to survive cold temperatures in winters, are now being turned into scenic spots. Tourists also bring heavy traffic to the island, which is a potential threat to this slow-moving reptile. Mulan, a young male released in Aug. 2011 (Table 1), was found to have been killed on a road several months after release. Snake-eating culture still exists in some of the armies and fire brigades. A male snake, Timon, was captured by soldiers in November 2011 during radio-tracking but was luckily rescued by the researcher (S.-P. Chou) who traced the signal to the military camp. Unfortunately, the second largest female, PM021 (Minnie Mouse), was killed and eaten by local people in 2012 during our radio-tracking research. The same tragedy repeated once again on PM021 (Pocahontas) in the spring of 2013. The increasing python population on Kinmen has also caused a conflict between scientists and local villagers, whose farm animals and pets may be at risk of becoming python prey. One snake among those recently released was captured again by a local farmer and is now kept as a pet in his farm with no lawful solution. The frequent bad news from these released pythons indicated that the demographic size of this population might be much smaller than our previous speculation. Since Aug. 2012, the research team has faced a shortage of financial support and had no choice but to stop tracking snakes which already have implanted radio transmitters. 


\section{Conclusions}

After the 40-year expiration, the pythons recovered in Kinmen since the army gradually retreated from the islands. Molecular phylogenetic studies illustrated that the python population is native. Recovery of this population provides an excellent chance to study this secretive animal within their native range. However, conservation of the python in Kinmen has encountered all possible problems of other snakes throughout the world: misconceptions, lack of concern, lack of studies, and a shortage of conservation resources. Therefore, we call for greater attention to research and conservation of this fantastic organism. The python represents a novel case of an important wildlife refuge inadvertently preserved by the creation of a demilitarized zone (DMZ) and should undoubtedly be treated as a flagship species of this special habitat.

\section{Competing interests}

The author declares that they have no competing interests.

\section{Authors' contributions}

CWY and SML originally formulated the idea; HYC and SML organized the research project. YPL and SPC carried out the molecular genetic studies and field works; YHL and RTZ did the surgeries. YLC and YT carried out the molecular works of the Chinese samples. SML organized the data and wrote the manuscript. All authors have read and approved the final manuscript.

\section{Acknowledgments}

We thank Ms. A.-C. Li from the Kinmen County Government for her kind help during our research. We are also grateful to Dr. H.-C. Lin and Ms. C.-Y. Chen from the Conservation Division, Forestry Bureau, Council of Agriculture for their assistance with the research project. We are grateful to M.E. Dorcas for carefully revising the manuscript. This study was supported by the Forestry Bureau, Council of Agriculture, Taiwan.

\section{Author details}

${ }^{1}$ Department of Life Science, National Taiwan Normal University, No. 88, Tingchou Road, Section 4, Taipei 11677, Taiwan. ${ }^{2}$ Veterinary Division, Taipei Zoo, No. 30, Xinguang Road, Section 2, Taipei 11656, Taiwan. ${ }^{3}$ College of Life Sciences, Fujian Normal University, Fuzhou, Fujian Province 350117, People's Republic of China. ${ }^{4}$ Fuzhou Zoo, No. 7, Chiqiao Village, Jinan District, Fuzhou, Fujian Province 350011, People's Republic of China. ${ }^{5}$ Conservation Division, Forestry Bureau, Council of Agriculture, No. 2, Hangzhou South Road, Section 1, Taipei 10050, Taiwan. ${ }^{6}$ Herpetological Associates, 575 Toms River Road, Route 571, Jackson, NJ 08527, USA.

Received: 6 November 2012 Accepted: 22 January 2013 Published: 10 September 2013

\section{References}

Avery ML, Engeman RM, Keacher KL, Humphrey JS, Bruce WE, Mathies TC, Mauldin RE (2010) Cold weather and the potential range of invasive Burmese pythons. Biol Invasions 12:3649-3652

Barker DG, Barker TM (2010) A critique of the analysis used to predict the climate space of the Burmese python in the United States by Rodda et al. $(2008,2009)$ and Reed and Rodda. Bull. Chicago Herpetol. Soc 45:97-106

Chang YM, Hatch KA, Ding TS, Eggett DL, Yuan HW, Roeder BL (2008) Using stable isotopes to unravel and predict the origins of great cormorants Phalacrocorax carbo sinensis) overwintering at Kinmen. Rapid Commun Mass Spectr 22:1235-1244

Chen CP, Yeh HY, Lin PF (2004) Conservation of the horseshoe crab at Kinmen, Taiwan: strategies and practices. Biodivers Conserv 13:1889-1904

Chen TH, Lue KY (2010) Population status and distribution of freshwater turtles in Taiwan. Oryx 44:261-266
Clement M, Posada D, Crandall KA (2000) TCS: a computer program to estimate gene genealogies. Mol Ecol 9:1657-1659

Dillon TC, Wikramanayake ED (1997) Parks, peace and progress: a forum for transboundary conservation in Indo-China. Parks 7:36-51

Dong S, Kumazawa Y (2005) Complete mitochondrial DNA sequences of six snakes: phylogenetic relationships and molecular evolution of genomic features. J Mol Evol 61:12-22

Dorcas ME, Willson JD, Gibbons JW (2011) Can invasive Burmese pythons inhabit temperate regions of the southeastern United States? Biol Invasions 13:793-802

Dove CJ, Snow RW, Rochford MR, Mazzotti FJ (2011) Birds consumed by the invasive Burmese python (Python molurus bivittatus) in Everglades National Park, Florida, USA. Wilson J Ornithol 123:126-131

Draulans D, Krunkelsven EV (2002) The impact of war on forest areas in the Democratic Republic of Congo. Oryx 36:35-40

Dudley JP, Ginsberg JR, Plumptre AJ, Hart JA, Campos LC (2002) Effects of war and civil strife on wildlife and wildlife habitats. Conserv Biol 16:319-329

Engeman R, Jacobson E, Avery ML, Meshaka WE, Jr (2011) The aggressive invasion of exotic reptiles in Florida with a focus on prominent species: a review. Curr Zool 57:599-612

Fairhead J, Leach M (1995) False forest history, complicit social analysis: rethinking some West African environmental narratives. World Develop 23:1023-1035

Guindon S, Dufayard JF, Lefort V, Anisimova M, Hordijk W, Gascuel O (2010) New algorithms and methods to estimate maximum-likelihood phylogenies: assessing the performance of PhyML 3.0. Syst Biol 59:307-321

Hart KM, Schofield PJ, Gregoire DR (2011) Experimentally derived salinity tolerance of hatchling Burmese pythons (Python molurus bivittatus) from the Everglades, Florida (USA). J Exp Mar Biol Ecol 413:56-59

Higuchi H, Ozaki K, Fujita G, Minton J, Ueta M, Soma M, Mita N (1996) Satellite tracking of White-naped Crane migration and the importance of the Korean demilitarized zone. Conserv Biol 10:806-812

Huelsenbeck JP, Ronquist F (2001) MRBAYES: Bayesian inference of phylogenetic trees. Bioinformatics 17:754-755

Hu L (1976) A memory in Kinmen. Li Ming Cultural Enterprise, Taipei, Taiwan (in Chinese)

Hung CM, Li SH, Lee LL (2004) Faecal DNA typing to determine the abundance and spatial organisation of otters (Lutra lutra) along two stream systems in Kinmen. Anim Conserv 7:301-311

Hung HY, Lin RC, Yao CT, Liu Y, Li SH (2009) Subspecies identification of Ring-necked pheasant on Kinmen Island. J Natl Park 19:21-31

Kim KC (1997) Preserving biodiversity in Korea's demilitarized zone. Science 278:242-243

Mazzotti FJ, Cherkiss MS, Hart KM, Snow RW, Rochford MR, Dorcas ME, Reed RN (2011) Cold-induced mortality of invasive Burmese pythons in south Florida. Biol Invasions 13:143-151

McNeely JA (2003) Conserving forest biodiversity in times of violent conflict. Oryx 30:142-152

Posada D (2008) jModelTest: phylogenetic model averaging. Mol Biol Evol 25:1253-1256

Pyron RA, Burbrink FT, Guiher TJ (2008) Claims of potential expansion throughout the U.S. by invasive python species are contradicted by ecological niche models. PLoS One 3:e2931

Rodda GH, Jarnevich CS, Reed RD (2009) What parts of the US mainland are climatically suitable for invasive alien pythons spreading from Everglades National Park? Biol. Invasions 11:241-252

Rodda GH, Jarnevich CS, Reed RN (2011) Challenges in identifying sites climatically matched to the native ranges of animal invaders. PLoS One 6:e14670

Shiang G, Li PS, Yang YJ (2009) A field guide to amphibians and reptiles of Taiwan. Owl Publishing House, Taipei, Taipei (in Chinese)

Swofford DL (1998) PAUP*: phylogenetic analysis using parsimony (and other methods). Sinauer Associates, Sunderland, MA

Wang YP, Siefferman L, Wang YJ, Ding TS, Chiou CR, Shieh BS, et al. (2009) Nest site restoration increases the breeding density of Blue-tailed Bee-Eaters. Biol Conserv 142:1748-1753

You CW, Lin YP, Chou SP, Lin SM (2011) Caution for the huge snakes! A formal record of the Burmese python in Kinmen. In: 2011 Symposium on Animal Behavior, Ecology and Environmental Education, Taipei. 17-18 Jan. 2011 

and water quality. J Nat Hist 40:485-493

Zhao EM (1998) China red data book of endangered animals - Amphibia and Reptilia. Science Press, Beijing (in Chinese)

Zhao EM, Huang MH, Zong Y (ed) (1998) Fauna Sinica. Reptilia Vol. 3. Squamata, Serpentes. Science Press, Beijing (in Chinese)

doi:10.1186/1810-522X-52-8

Cite this article as: You et al:: Return of the pythons: first formal records,

with a special note on recovery of the Burmese python in the

demilitarized Kinmen islands. Zoological Studies 2013 52:8.

\section{Submit your manuscript to a SpringerOpen ${ }^{\odot}$} journal and benefit from:

- Convenient online submission

- Rigorous peer review

- Immediate publication on acceptance

- Open access: articles freely available online

- High visibility within the field

- Retaining the copyright to your article

Submit your next manuscript at $>$ springeropen.com 